\title{
RELEASE OF DOPAMINE FROM COAGGREGATE CULTURES OF MESENCEPHALIC TEGMENTUM AND CORPUS STRIATUM ${ }^{1}$
}

\author{
ISMAIL A. SHALABY, CONNIE KOTAKE, PHILIP C. HOFFMANN, AND ALFRED HELLER ${ }^{2}$ \\ Department of Pharmacological and Physiological Sciences, The University of Chicago, Chicago, Illinois 60637
}

Received January 28, 1983; Accepted March 10, 1983

\begin{abstract}
Dissociated dopamine (DA) neurons from 14-day fetal mice were dissected from the rostral mesencephalic tegmentum (RMT) and were allowed to reaggregate in vitro with cells from the corpus striatum (CS). As previously demonstrated under these conditions, DA neurons develop punctate fluorescent varicosities and the capacity to synthesize, accumulate, and retain DA (Kotake, C., P. C. Hoffmann, and A. Heller (1982) J. Neurosci. 2: 1307-1315). After 17 to 22 days in culture, the RMT-CS coaggregates were assessed for their ability to release DA. Coaggregates were incubated in $5.6 \times 10^{-6} \mathrm{M}\left[{ }^{3} \mathrm{H}\right] \mathrm{DA}$, washed, and then superfused at $100 \mu \mathrm{l} / \mathrm{min}$ for $2 \mathrm{hr}$. Fractions were collected every $2 \mathrm{~min}$. Basal efflux of $\left[{ }^{3} \mathrm{H}\right] \mathrm{DA} / 2 \mathrm{~min}$ was $1 \%$ of tissue stores of ${ }^{3} \mathrm{H} . \mathrm{K}^{+}, 70 \mathrm{~mm}$ infused for 8 min induced a peak release of $5.87 \%$ of tissue stores of ${ }^{3} \mathrm{H}$, and $50 \mathrm{mM} \mathrm{K}{ }^{+}$induced a peak release of $2.13 \%$. The potassium-induced release of $\left[{ }^{3} \mathrm{H} J \mathrm{DA}\right.$ was calcium dependent. When $d$-amphetamine was infused for $12 \mathrm{~min}, 100 \mu \mathrm{M}$ solutions induced a peak release of $8.91 \%, 10 \mu \mathrm{M}$ induced a peak release of $4.36 \%$, and $1 \mu \mathrm{M}$ induced a peak release of $1.85 \%$ of tissue stores of ${ }^{3} \mathrm{II}$. Substance $\mathrm{P}$ at $100 \mu \mathrm{M}$ induced a peak release of $2.19 \%$ of tissue stores of ${ }^{3} \mathrm{H}$. Tetrodotoxin $(0.5$ and $2.5 \mu \mathrm{M})$ decreased basal efflux by $40 \%$, blocked substance P-induced release, but did not affect either potassium- or $d$-amphetamine-induced release of $\left[{ }^{3} \mathrm{H}\right]$ dopamine.
\end{abstract}

Dissociated dopamine (DA) cells dissected from the rostral mesencephalic tegmentum (RMT), when allowed to reaggregate in a rotary culture system, exhibit a preferential reassociation with each other (Hemmendinger et al., 1981a). Moreover, dissociated DA cells of the RMT allowed to reaggregate with cells from the corpus striatum (CS) exhibit punctate fluorescent varicosities indicative of axonal proliferation. This axonal proliferation, resembling typical adult patterns, occurs only in the presence of appropriate targets such as cells from the striatum and frontal cortex (Hemmendinger et al., 1981b). The intensity of the fluorescent patterns increases between 3 and 21 days in culture (Kotake et al., 1982). These RMT-CS coaggregates also exhibit a developmental increase in endogenous DA levels, in DA uptake and retention, and in tyrosine hydroxylase activity (Kotake et al., 1982).

The ability of a depolarized neuron to release its neurotransmitter is obviously a critical aspect of its func-

${ }^{1}$ This research was supported by United States Public Health Service Grant MH 28942. I. A. S. was a Pharmacological Sciences predoctoral trainee on GM 07151-08. We thank Eligia Dimapilis and Francis Karapas for technical assistance, and Jo DeGroot for manuscript preparation.

${ }^{2}$ To whom correspondence should be addressed. tional effectiveness in synaptic communication. In this regard, we have in the present study demonstrated the ability of coaggregate cultures of RMT-CS neurons to release $\left[{ }^{3} \mathrm{H}\right] \mathrm{DA}$ in response to potassium, $d$-amphetamine, and substance $P$. These results show that embryonic dopamine neurons develop transmitter release characteristics indistinguishable from those observed in vivo, when these neurons are coaggregated with cells from the CS.

\section{Materials and Methods}

\section{Preparation of RMT-CS coaggregates}

Embryos were removed from pregnant C57BL/6J mice (Jackson Laboratories) on the 14th day of gestation. Tissue of the rostral mesencephalic tegmentum (RMT) was dissected according to its histofluorescent localization in mouse embryos of this age (Golden, 1973). The corpus striatum (CS) was separated from the septum and dissected free from the surrounding cortex. Brain tissue was dissociated and aggregated as previously described (Hemmendinger et al., 1981b). Briefly, the dissected minced tissue was incubated for $20 \mathrm{~min}$ in $\mathrm{Ca}^{2+}-\mathrm{Mg}^{2+}$. free Tyrode's solution and then for $35 \mathrm{~min}$ in $0.67 \%$ trypsin. The tissue was then dissociated by gentle flushing through a fine-bore Pasteur pipette. Cells were then 
allowed to aggregate in 25-ml Erlenmeyer flasks containing $3.5 \mathrm{ml}$ of initial culture medium $(100 \mathrm{ml}$ of Eagle's minimum medium (Microbiological Associates) to which was added $10 \mathrm{ml}$ of fetal bovine serum (GIBCO), $1 \mathrm{ml}$ of penicillin-streptomycin, and $2.5 \mathrm{ml}$ of DNase (Worthington) $(1 \mathrm{mg} / \mathrm{ml})$ ). Approximately $5 \times 10^{6}$ cells of each type were placed in the flasks. These flasks were then fitted with air-tight stoppers and placed in a rotary shakerincubator (New Brunswick) at $80 \mathrm{rpm}$ and $35^{\circ} \mathrm{C}$. After $24 \mathrm{hr}, 3.0 \mathrm{ml}$ of the medium were removed and replaced with $3.0 \mathrm{ml}$ of medium containing horse serum (GIBCO) in place of fetal bovine serum. Replacements of the medium $(3.0 \mathrm{ml})$ continued thereafter every 2 to 3 days, until the coaggregates were collected at 17 to 22 days in culture.

\section{Superfusion of tissue}

Superfusion experiments were performed in buffer containing $124 \mathrm{mM} \mathrm{NaCl}, 5.0 \mathrm{mM} \mathrm{KCl}, 25.9 \mathrm{mM} \mathrm{Na}-$ $\mathrm{HCO}_{3}, 1.3 \mathrm{mM} \mathrm{MgSO}_{4}, 1.2 \mathrm{mM} \mathrm{KH} \mathrm{PO}_{4}, 10.0 \mathrm{mM}$ glucose, $1.5 \mathrm{mM} \mathrm{CaCl}_{2}$, and $25 \mathrm{~mm}$ HEPES (Sigma) adjusted to a pH of 7.4. All solutions also contained $100 \mu \mathrm{M}$ pargyline and $20 \mu \mathrm{M}$ dithiothreitol (DTT). The osmolarity of all buffers was kept constant by an appropriate reduction in the $\mathrm{NaCl}$ concentration of the 50 and $70 \mathrm{mM} \mathrm{K}^{+}$ buffers. The superfusion chambers consisted of Millipore filter units $(10-\mathrm{mm}$ diameter $)$, in which the tissue was placed over $0.45-\mu \mathrm{m}$ pore filters. The filter units were connected to three-way valves that were connected with Nalge tubing ( $1 / 32$ in. inner diameters) to a multichannel peristaltic pump (DASAGA). This system permitted the introduction of up to three different solutions to the tissue without interruption of flow. The filter units were placed in a water bath at $37^{\circ} \mathrm{C}$. Outlets were placed in scintillation vials to collect the superfusates. Buffer and drug solutions were also prewarmed to $37^{\circ} \mathrm{C}$, and were continuously oxygenated by bubbling a mixture of $95 \%$ $\mathrm{O}_{2} / 5 \% \mathrm{CO}_{2}$.

\section{Uptake and release}

Ten microcuries of $\left[2,5,6-{ }^{3} \mathrm{H}\right]$ dopamine (DA) were evaporated to dryness by a stream of nitrogen and redissolved in 100 to $300 \mu$ l of oxygenated buffer (final concentration $\left.5.56 \times 10^{-6} \mathrm{M} \mathrm{DA}\right)$. Through high pressure liquid chromatography (HPLC) determination (see below) the purity of the $\left[{ }^{3} \mathrm{H}\right] \mathrm{DA}$ was determined to be $96 \%$. This solution was added to coaggregates (approximately 200 to $400 \mu \mathrm{g}$ of protein) that had been previously washed in the buffer solution. The tissue was placed in $1.0-\mathrm{ml}$ centrifuge tubes in a water bath at $37^{\circ} \mathrm{C}$ for $30 \mathrm{~min}$. Thereafter, the radioactive solution was aspirated and the tissue was washed six times with $1.0 \mathrm{ml}$ of ice-cold buffer. The tissue was then placed in the filter units in the water bath and superfused with the buffer for $20 \mathrm{~min}$ at $100 \mu \mathrm{l} / \mathrm{min}$ before fraction collection was started. Tissue was then superfused for 1 or $2 \mathrm{hr}$ depending on the experiment. Effluents from the tissue were collected in scintillation vials over 2 -min intervals. Ten milliliters of Aquasol were added and ${ }^{3} \mathrm{H}$ was counted in a Packard Tri-Carb C2425 scintillation counter (counting efficiency $34 \%$ ). Following superfusion the tissue was collected and sonicated in $300 \mu \mathrm{l}$ of $0.4 \mathrm{~N}$ perchloric acid. The homogenate was spun at $4200 \mathrm{rpm}$ for 25 min (Beckman J-6B), and $200 \mu \mathrm{l}$ of the supernatant were used to determine tissue ${ }^{3} \mathrm{H}$ content. The pellet was solubilized in $500 \mu \mathrm{l}$ of $0.1 \mathrm{~N} \mathrm{NaOH}$ to determine protein content (Lowry et al., 1951) using bovine serum albumin (BSA) as standard.

\section{Potassium and drug-induced release}

Twenty minutes from the start of the collection period, when basal efflux of $\left[{ }^{3} \mathrm{H}\right]$ dopamine had stabilized, solutions of high potassium $(50 \mathrm{mM}$ or $70 \mathrm{mM}$ ) were introduced for $8 \mathrm{~min}$, followed by normal buffer until $60 \mathrm{~min}$ into the collection period. At that time either $d$-amphetamine or substance $\mathrm{P}$ was introduced for $12 \mathrm{~min}$. While amphetamine was just dissolved in the buffer, substance $\mathrm{P}$ (SP) solutions, in addition, contained $10 \mu \mathrm{M}$ Bestatin or $50 \mu \mathrm{M}$ bacitracin to prevent enzymatic degradation (Lee et al., 1981) and 0.1\% BSA to prevent nonspecific absorption. The aminopeptidase inhibitors, which were introduced $1 \mathrm{hr}$ before SP, did not affect basal or potassium-induced $\left[{ }^{3} \mathrm{H}\right] \mathrm{DA}$ efflux.

To test the calcium dependency of the $\mathrm{K}^{+}$-induced release, a calcium-free buffer in which $\mathrm{Co}^{2+}$ substituted for $\mathrm{Ca}^{2+}$ was introduced 20 min before a second stimulation with a $70 \mathrm{mM} \mathrm{K}^{+}$(calcium-free) buffer was begun. $\mathrm{KH}_{2} \mathrm{PO}_{4}$ was removed from the $\mathrm{Co}^{2+}$ buffer to prevent precipitation. Buffer in which cobalt chloride substituted for calcium chloride was used because calcium-free buffer that contained $2.0 \mathrm{mM}$ EGTA, although blocking potassium-induced release of $\left[{ }^{3} \mathrm{H}\right] \mathrm{DA}$, led to marked fluctuations in basal efflux.

The ${ }^{3} \mathrm{H}$ effluent was analyzed for DA and its metabolites by HPLC (C. Kotake, T. G. Heffner, G. Vosmer, A. Heller, and L. S. Seiden, manuscript in preparation). DA and metabolites were separated on a reverse-phase column (Altech RSil C18 HL) through which a mobile phase (110 mM citric acid, $10 \mathrm{mM} \mathrm{Na} \mathrm{NPO}_{4}$, Na-EDTA 100 $\mathrm{mg} / \mathrm{liter}$, and $30 \mathrm{mg} / \mathrm{liter}$ of octyl sodium sulfate) was pumped at a rate of $1 \mathrm{ml} / \mathrm{min}$. The concentrations of DA and metabolites were determined by electrochemical detection (BAS LC2A) with a TI-8A custom cell thin layer transducer (BAS). The amperometric detector was connected to a time base chart recorder (Linear). The potential of the thin layer transducer was set at $+0.75 \mathrm{~V}$ versus a silver chloride reference electrode (RE-3, BAS). This system allowed for both the electrochemical detection of the catecholamines as well as their collection to measure ${ }^{3} \mathrm{H}$ content. DA and metabolite standards (homovanillic acid, 3-methoxytyramine, norepinephrine, dihydroxyphenylalanine) were added to the ${ }^{3} \mathrm{H}$ effluent which was then injected onto the column. The ${ }^{3} \mathrm{H}$ content of the buffer coeluting with the various catecholamine standards was then analyzed in a scintillation counter.

\section{Materials}

Dopamine and other catecholamine standards, bacitracin, Bestatin, dithiothreitol, BSA, pargyline, $d$-amphetamine sulfate, and substance $\mathrm{P}$ wcre all purchased from Sigma. Tetrodotoxin (TTX) was purchased from Calbiochem. $\left[2,5,6-{ }^{3} \mathrm{H}\right]$ Dopamine $(6$ to $18 \mathrm{Ci} / \mathrm{mmol}$ ) was purchased from Amersham. 


\section{Results}

Coaggregates of the RMT-CS cells used in these experiments were collected after 17 to 22 days in culture. At this stage of development many fluorescent cell bodies have formed profuse axonal networks. The axonal network, seen as prominent patches of punctate fluorescence, is quite similar to that seen in adult rat and mouse striata (Kotake et al., 1982).

Following an initial 20-min superfusion period, fractions of superfusates were collected over 2-min intervals for the course of experiment. 'Total ${ }^{3} \mathrm{H}$ released during the experiment added to the ${ }^{3} \mathrm{H}$ remaining in the tissue at the end of the experiment was taken as an estimate of the $\left[{ }^{3} \mathrm{H}\right] \mathrm{DA}$ uptake and retention in the RMT-CS coaggregates. DA uptake was calculated to be $79.40 \pm$ $4.80(\mathrm{SEM}) \mathrm{pmol} / \mathrm{mg}$ of protein. This value is quite comparable to our previous results on DA uptake and retention using nonradioisotopic procedures (Kotake et al., 1982).

The efflux of $\left[{ }^{3} \mathrm{H}\right] \mathrm{DA}$ for each 2-min fraction was expressed as a percentage of the ${ }^{3} \mathrm{H}$ present in the tissue during the preceding $2 \mathrm{~min}$. Total tissue stores of ${ }^{3} \mathrm{H}$ were estimated by summing the ${ }^{3} \mathrm{H}$ remaining in the tissue at the end of the experiment with that released during the course of superfusion. The total amount of ${ }^{3} \mathrm{H}$ released in response to stimulation was also calculated. This was accomplished by summing all the ${ }^{3} \mathrm{H}$ in fractions during which potassium and drug-induced release of $\left[{ }^{3} \mathrm{H}\right] \mathrm{DA}$ was occurring. For potassium and substance $\mathrm{P}$ this represented a 36-min interval and for $d$-amphetamine $56 \mathrm{~min}$. The results were expressed as percentage of tissue ${ }^{3} \mathrm{H}$ present prior to potassium or drug superfusion.

The data are presented as means \pm standard errors of the mean (SEM). Analyses of variance were performed on the data to test the main effects of potassium, $d$ amphetamine, and substance P. Student's $t$ tests followed the analyses of variance to analyze individual dose differences. Between two and five flasks of aggregates were used for each condition. Criterion of statistical significance was taken to be $p<0.05$.

\section{Potassium-induced release of $\left[{ }^{3} H\right]$ dopamine}

After tissue was superfused for $20 \mathrm{~min}$, basal efflux of $\left[{ }^{3} \mathrm{H}\right] \mathrm{DA}$ was reached, at which time fraction collection was started. Basal efflux of $\left[{ }^{3} \mathrm{H}\right] \mathrm{DA}$, when expressed as percentage of tissue stores of ${ }^{3} \mathrm{H} / 2 \mathrm{~min}$, represented about $1 \%$ (Fig. 1). Fifty and $70 \mathrm{~mm}$ potassium, when introduced for $8 \mathrm{~min}$, induced peak releases of $2.13 \pm$ $0.20 \%$ and $5.87 \pm 0.53 \%$ of tissue stores, respectively. The total amount of $\left[{ }^{3} \mathrm{H}\right] \mathrm{DA}$ released by 50 and $70 \mathrm{mM}$ $\mathrm{K}^{+}$during a 36 -min period was $22.55 \pm 2.69 \%$ and 33.65 $\pm 1.76 \%$, respectively, compared to $15.17 \pm 0.20 \%$ for nonstimulated controls. Statistical analysis revealed that $70 \mathrm{mM} \mathrm{K}{ }^{+}$induced a greater release of $\left[{ }^{3} \mathrm{H}\right] \mathrm{DA}$ than 50 $\mathrm{mM} \mathrm{K} \mathrm{K}^{+}$.

The calcium dependency of the $\left[{ }^{3} \mathrm{H}\right] \mathrm{DA}$ released by 70 $\mathrm{mM} \mathrm{K}^{+}$was examined (Fig. 2). Following the first potassium superfusion and 20 min before a second, some coaggregates were exposed to buffer in which $\mathrm{Co}^{2+}$ was substituted for $\mathrm{Ca}^{2+}$ (see "Materials and Methods"). The coaggregates were then superfused with another 8-min pulse of $70 \mathrm{mM} \mathrm{K}^{+}\left(\mathrm{Ca}^{2+}\right.$ free). The ratio of the efflux resulting from that of the second stimulation $\left(\mathrm{S}_{2}\right)$ to the first $\left(S_{1}\right)$ was calculated. While $S_{2} / S_{1}$ for controls was $0.87 \pm 0.10$, the ratio for coaggregates exposed to a $\mathrm{Co}^{2+}$ substituted buffer was $0.20 \pm 0.04$, a significant reduction. The calcium-free, cobalt-substituted buffer did not significantly affect basal efflux of $\left[{ }^{3} \mathrm{H}\right] \mathrm{DA}$.

HPLC analysis of the ${ }^{3} \mathrm{H}$ superfusates indicated that

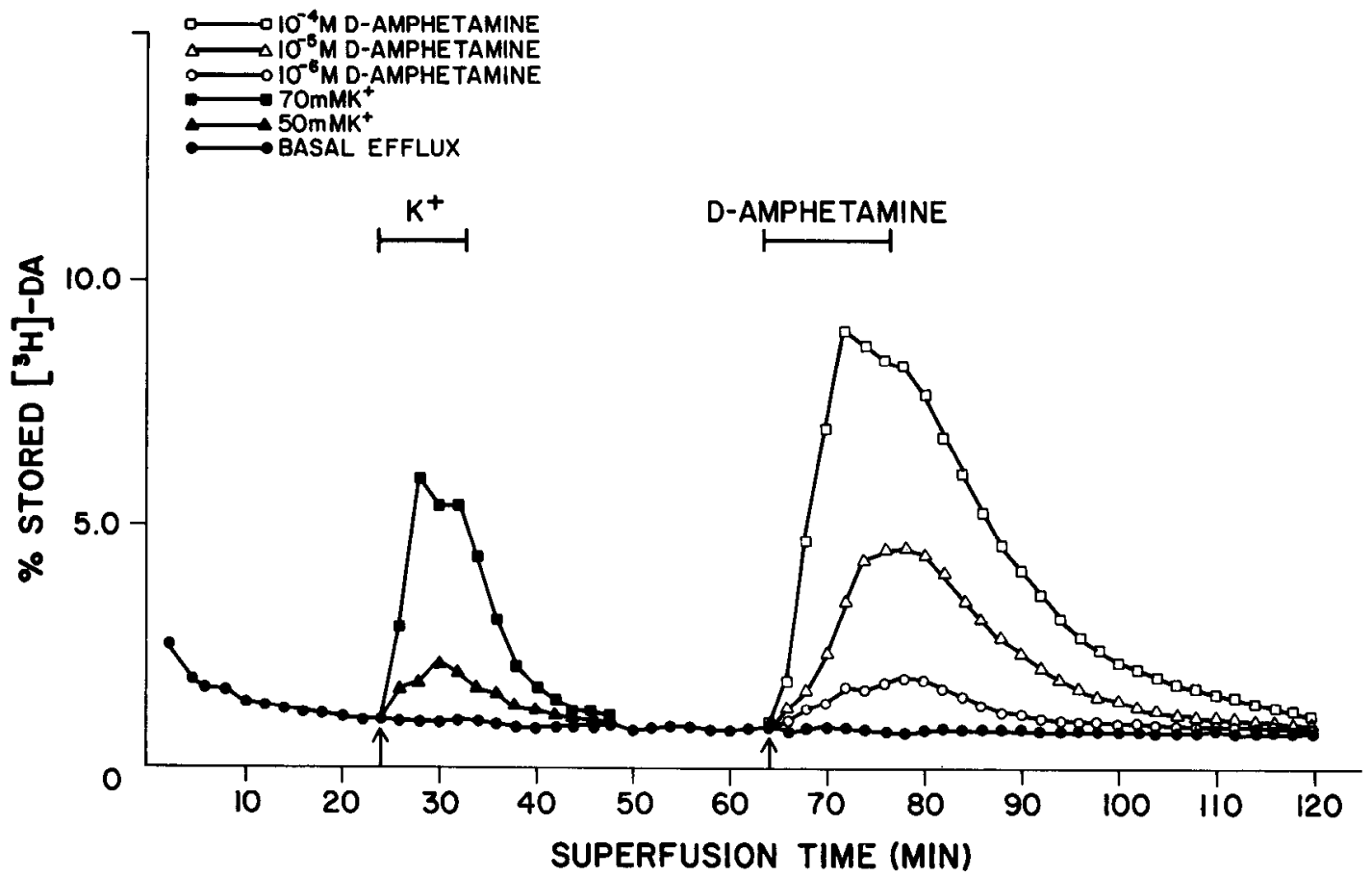

Figure 1. Effect of potassium ( $8 \mathrm{~min})$ and $d$-amphetamine $(12 \mathrm{~min})$ on release of $\left[{ }^{3} \mathrm{H}\right] \mathrm{DA}$ from RMT-CS coaggregates. 
during basal efflux DA represented $49.0 \pm 1.0 \%$ and 3 methoxytyramine $(3-\mathrm{MT})$ represented $51.0 \pm 0.95 \%$ of the total ${ }^{3} \mathrm{H}$. During potassium as well as drug-induced (see below) release, DA was $75.9 \pm 3.5 \%$ and $3-\mathrm{MT}$ was $24.1 \pm 3.5 \%$ of ${ }^{3} \mathrm{H}$ in the superfusates. No other ${ }^{3} \mathrm{H}$ metabolite was detectable.

\section{Amphetamine-induced release of $\left[{ }^{3} \mathrm{H}\right]$ dopamine}

Some coaggregates, after being exposed to an 8-min pulse of potassium, were later superfused with either 100 $\mu \mathrm{M}, 10 \mu \mathrm{M}$, or $1 \mu \mathrm{M} d$-amphetamine for $12 \mathrm{~min}$ (Fig. 1). As can be seen, there was a concentration-dependent increase in $\left[{ }^{3} \mathrm{H}\right] \mathrm{DA}$ efflux. One hundred micromolar $d$ amphetamine induced a peak release of $8.91 \pm 0.77 \%$ of tissue ${ }^{3} \mathrm{H}$ and a total release over a $56-\mathrm{min}$ period of $68.01 \pm 1.26 \%$. Ten micromolar induced a peak release of $4.36 \pm 0.64 \%$ of tissue ${ }^{3} \mathrm{H}$ stores and a total release of $45.18 \pm 4.45 \%$. The peak release by $1 \mu \mathrm{M} d$-amphetamine $(1.85 \pm 0.32 \%)$ was not statistically significant $(0.10>p$ $>0.05$ ) when compared to nonstimulated controls. Total release of $\left[{ }^{3} \mathrm{H}\right] \mathrm{DA}$ by $1 \mu \mathrm{M} d$-amphetamine, $35.83 \pm$ $4.18 \%$, also was not statistically significant $(0.10>p>$ 0.05 ). Nonstimulated controls released a total of $20.15 \pm$ $0.78 \%$ of tissue ${ }^{3} \mathrm{H}$. One hundred micromolar $d$-amphetamine induced a significantly greater $\left[{ }^{3} \mathrm{H}\right] \mathrm{DA}$ release than $10 \mu \mathrm{M}$ or $1 \mu \mathrm{M}$. Ten micromolar $d$-amphetamine induced a significantly greater release of $\left[{ }^{3} \mathrm{H}\right] \mathrm{DA}$ than 1 $\mu \mathrm{M}$.

\section{Substance P-induced release of $\left[{ }^{3} H\right]$ dopamine}

Coaggregates exposed to a 12-min pulse of SP exhibited a concentration-dependent increase in $\left[{ }^{3} \mathrm{H}\right] \mathrm{DA}$ release (Fig. 3A). The $100 \mu \mathrm{M}$ concentration of SP increased $\left[{ }^{3} \mathrm{H}\right] \mathrm{DA}$ release to a peak of $2.19 \pm 0.21 \%$ of tissue stores and a total release over a 36 -min period of $24.87 \pm 0.94 \%$. This concentration increased $\left[{ }^{3} \mathrm{H}\right] \mathrm{DA}$ efflux to a statistically significant degree over nonstimulated controls, which released a total of $13.81 \pm 0.58 \%$ of ${ }^{3} \mathrm{H}$ tissue stores over the same 36-min interval. One and $10 \mu \mathrm{M}$ SP did not significantly increase $\left[{ }^{3} \mathrm{H}\right] \mathrm{DA}$ efflux, with both reaching peaks of $1.14 \%$ of tissue ${ }^{3} \mathrm{H}$ stores. Total release for $10 \mu \mathrm{M}$ SP was $17.01 \pm 1.79 \%$, and for $1 \mu \mathrm{M} \mathrm{SP}$ it was $16.37 \pm 2.21 \%$ of tissue stores of ${ }^{3} \mathrm{H}$.

\section{Effects of tetrodotoxin}

The effects of TTX ( 0.5 and $2.5 \mu \mathrm{M})$ on potassium, $d$ amphetamine, and SP-induced release of $\left[{ }^{3} \mathrm{H}\right] \mathrm{DA}$ was assessed. In these experiments coaggregates were continuously superfused with solutions containing TTX. TTX at both concentrations suppressed basal $\left[{ }^{3} \mathrm{H}\right] \mathrm{DA}$ efflux by about $40 \%$. The total ${ }^{3} \mathrm{H}$ efflux calculated over the first 20 min of fraction collection in controls was 13.82 $\pm 0.95 \%$. Under TTX this represented $8.57 \pm 0.66 \%$ for both 0.5 and $2.5 \mu \mathrm{M}$. This suppression of basal efflux by TTX was statistically significant.

Tetrodotoxin, at both concentrations, also significantly blocked the substance $\mathrm{P}(100 \mu \mathrm{M})$ stimulation of $\left[{ }^{3} \mathrm{H}\right] \mathrm{DA}$ release (Fig. $3 B$ ). Peak release of $\left[{ }^{3} \mathrm{H}\right] \mathrm{DA}$ with $10^{-4} \mathrm{M}$ SP under both doses of TTX was $0.67 \pm 0.41$. TTX did not affect either potassium $(70 \mathrm{~mm})$ or $d$ amphetamine (10 and $100 \mu \mathrm{M})$-induced release of $\left[{ }^{3} \mathrm{H}\right]$ dopamine.

\section{Discussion}

This study has demonstrated that dissociated dopamine neurons of the rostral mesencephalic tegmentum, aggregated with striatal cells, actively release dopamine. High $\mathrm{K}^{+}$, substance $\mathrm{P}$, and $d$-amphetamine all stimulate the $\left[{ }^{3} \mathrm{H}\right] \mathrm{DA}$ release in a concentration-dependent manner. The demonstration of depolarization-induced release of DA is essential in supporting our argument that

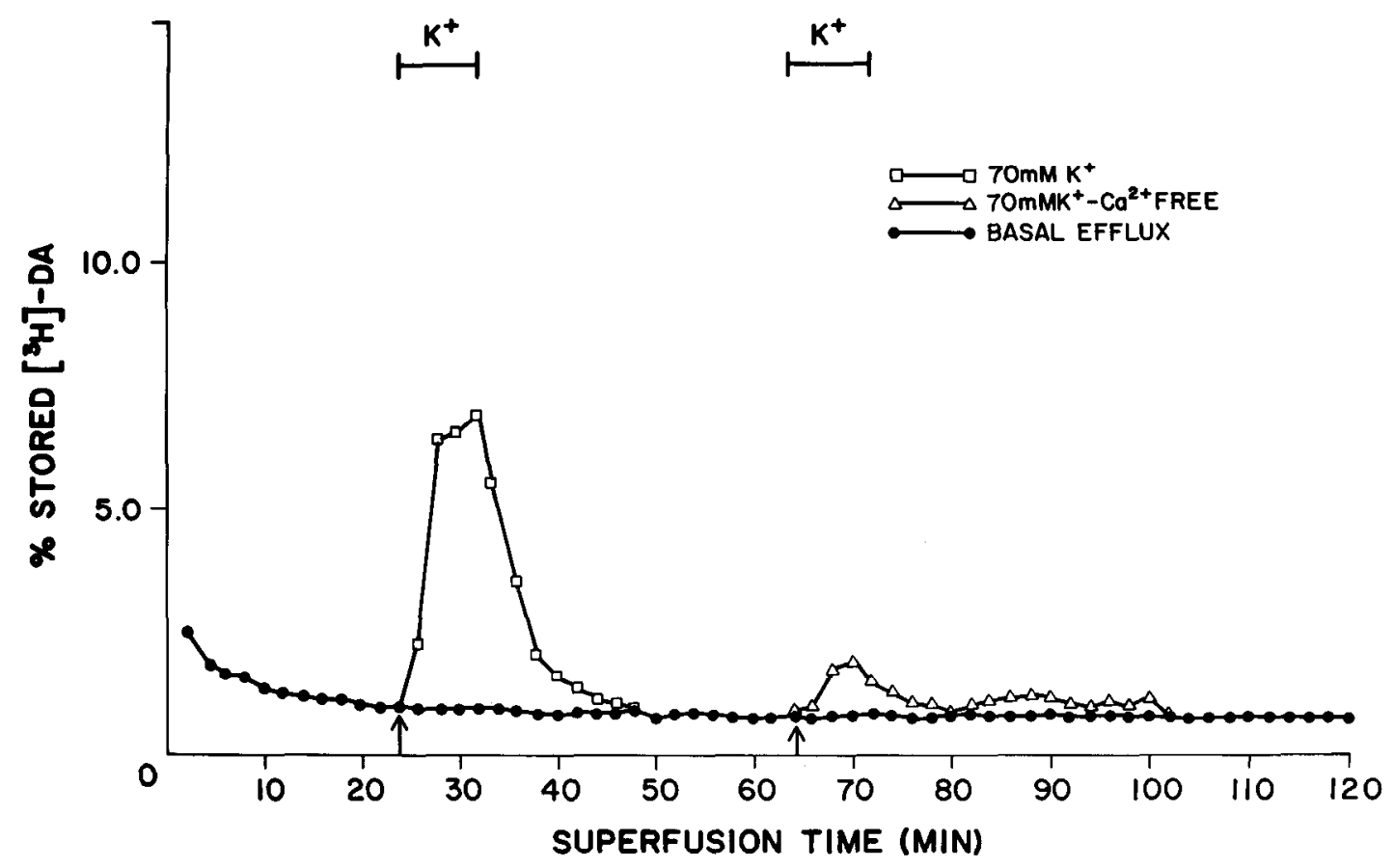

Figure 2. The effect of a $\mathrm{Ca}^{2+}$-free, $\mathrm{Co}^{2+}$-substituted buffer on the release of $\left[{ }^{3} \mathrm{H}\right] \mathrm{DA}$ induced by $70 \mathrm{mM} \mathrm{K} \mathrm{K}^{+}$. 


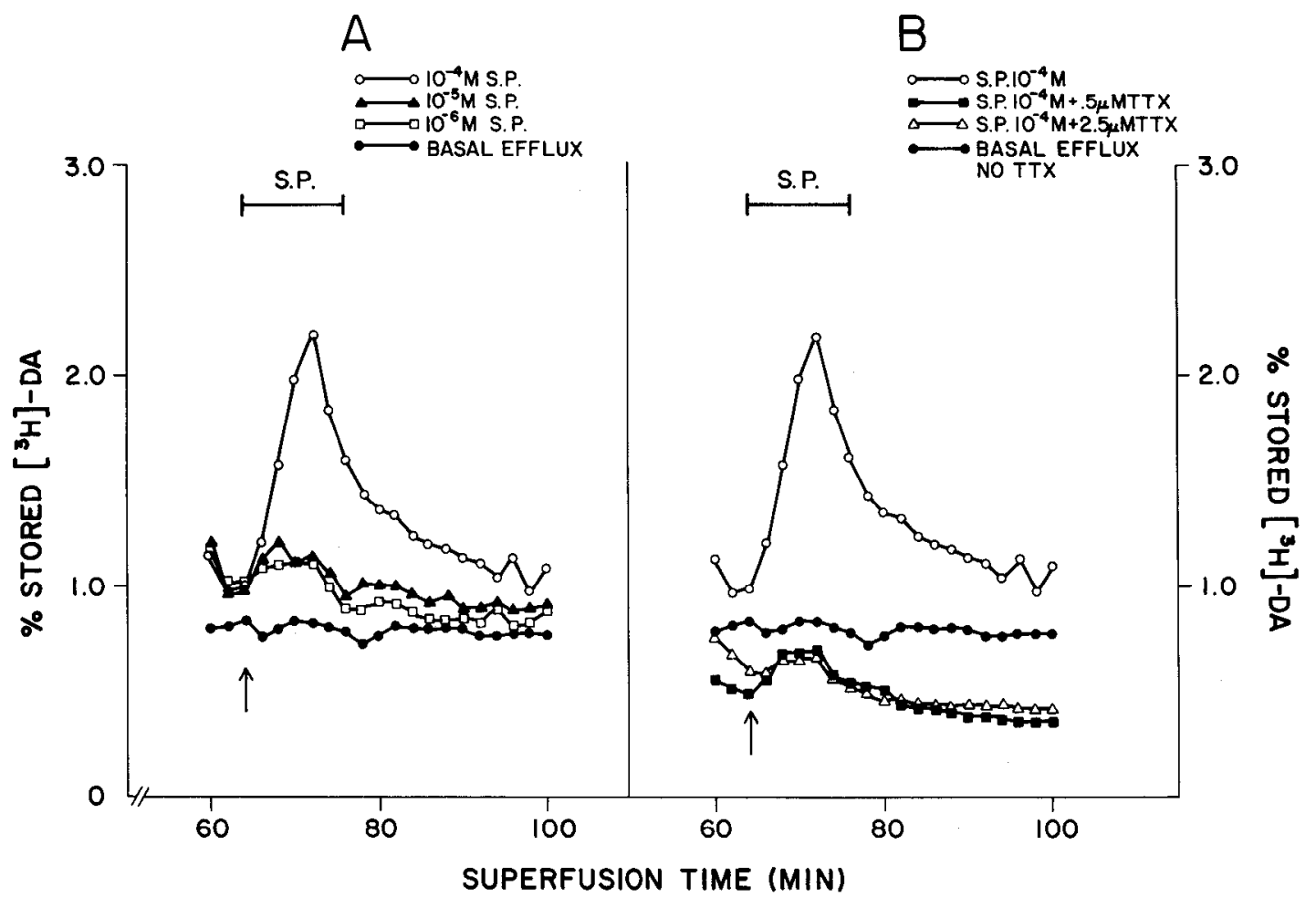

Figure 3. A, Effect of substance P (12 min) on $\left[{ }^{3} \mathrm{H}\right] \mathrm{DA}$ release from RMT-CS coaggregates. $B$, Effect of tetrodotoxin on substance $\mathrm{P}$-induced release of $\left[{ }^{3} \mathrm{H}\right] \mathrm{DA}$ from RMT-CS coaggregates.

this aggregate system represents a useful in vitro model for the DA nigrostriatal neurons.

The neurons in the RMT-CS coaggregate cultures release $\left[{ }^{3} \mathrm{H}\right] \mathrm{DA}$ with a basal efflux rate of about $1 \%$ of tissue stores of ${ }^{3} \mathrm{H}$ every $2 \mathrm{~min}$. This basal release partly represents active $\left[{ }^{3} \mathrm{H}\right] \mathrm{DA}$ secretion by neurons, inasmuch as TTX at 0.5 and $2.5 \mu \mathrm{M}$ decreased the basal efflux by $40 \%$. TTX is believed to block voltage-dependent $\mathrm{Na}^{+}$channels (Catterall, 1980). Because DA neurons in the RMT-CS coaggregates exhibit TTX-sensitive DA release, it seems quite likely that they are spontaneously active.

To test whether neurons in these cultures can release DA in response to depolarization, we investigated the effects of high potassium. RMT-CS coaggregates released $\left[{ }^{3} \mathrm{H}\right] \mathrm{DA}$ in a concentration-dependent manner with 50 and $70 \mathrm{mM} \mathrm{K}$. The potassium-induced release was calcium dependent. The release of $\left[{ }^{3} \mathrm{H}\right] \mathrm{DA}$ by $70 \mathrm{~mm}$ $\mathrm{K}^{+}$was suppressed in a calcium-free medium, as well as in a medium in which $\mathrm{Co}^{2+}$ substituted for $\mathrm{Ca}^{2+} \cdot \mathrm{Co}^{2+}(3$ $\mathrm{mM})$ in the presence of $\mathrm{Ca}^{2+}$ inhibited the release of $\left[{ }^{3} \mathrm{H}\right]$ DA by $70 \mathrm{~mm} \mathrm{~K} \mathrm{~K}^{+}$by $80 \%$ (I. A. Shalaby, S. B. Freedman, and R. J. Miller, manuscript in preparation). Cobalt has been demonstrated to block calcium channels in a variety of tissues (Hagiwara and Byerly, 1981).

High potassium solutions have been extensively used to investigate transmitter release processes. Potassiuminduced depolarization, and subsequent transmitter release, has been shown to be dependent on $\mathrm{Ca}^{2+}$ concentration but, unlike electrical field stimulation, does not act through voltage-dependent $\mathrm{Na}^{+}$channels (Orrego, 1979; Paton, 1979). In the present study just such a pattern of results was observed. Potassium-induced re- lease of $\left[{ }^{3} \mathrm{H}\right] \mathrm{DA}$ in RMT-CS coaggregates was calcium dependent (see above) but was not affected by $2.5 \mu \mathrm{M}$ TTX. The basal efflux rates, as well as the magnitude of the potassium-induced release of $\left[{ }^{3} \mathrm{H}\right] \mathrm{DA}$ in the RMTCS coaggregates, are quite comparable to values observed in in vitro preparations from the adult brain (Arbilla and Langer, 1980; Mulder et al., 1975).

d-Amphetamine induced a concentration-dependent increase in $\left[{ }^{3} \mathrm{H}\right] \mathrm{DA}$ release from RMT-CS coaggregates. Moreover, concentrations of $d$-amphetamine effective in inducing DA release from adult striatal slices (Thompson et al., 1981; Caviness and Wightman, 1982) were effective in stimulating $\left[{ }^{3} \mathrm{H}\right] \mathrm{DA}$ release from RMT-CS coaggregates. Amphetamine is thought to act on catecholamine neurons by displacing the transmitters from storage vesicles and preventing their subsequent reuptake (Trendelenburg, 1979). The amphetamine-induced release of DA is much like tyramine's effects in that regard, a process that does not involve depolarization (Trendelenburg, 1979) and does not depend on $\mathrm{Ca}^{2+}$ (Schwarz et al., 1980). As expected then, TTX did not affect $d$-amphetamine-induced release of $\left[{ }^{3} \mathrm{H}\right] \mathrm{DA}$ from RMT-CS coaggregate cultures.

Substance $\mathrm{P}$ neurons, originating in the striatum, are thought to form an excitatory input to nigral DA neurons (Nicoll et al., 1980). SP increases $\left[{ }^{3} \mathrm{H}\right] \mathrm{DA}$ release in substantia nigra slices (Reubi et al., 1978), and, when the peptide is infused through cannulae in vivo in cats, there is an increase in $\left[{ }^{3} \mathrm{H}\right] \mathrm{DA}$ release in the ipsilateral striatum (Cheramy et al., 1981). In the RMT-CS coaggregate cultures, SP induced stimulation of $\left[{ }^{3} \mathrm{H}\right] \mathrm{DA}$ release. Moreover, it is quite probable that SP acts by depolarizing DA neurons in inducing release, since the effect 
was suppressed by 0.5 and $2.5 \mu \mathrm{M}$ TTX. A high concentration of substance $\mathrm{P}$ was required to obtain a statistically significant release of $\left[{ }^{3} \mathrm{H}\right] \mathrm{DA}$. Substance $\mathrm{P}$ could be intrinsically of low potency in stimulating release, or it may be degraded despite the presence of peptidase inhibitors (Lee et al., 1981).

Release of $\left[{ }^{3} \mathrm{H}\right]$ catecholamines has previously been demonstrated in whole and midbrain aggregate cultures (Honegger and Richelson, 1979; Majocha et al., 1981). For cxample, Majocha et al. (1981) obtained release of $\left[{ }^{3} \mathrm{H}\right]$ norepinephrine (NE) in whole brain aggregate cultures with a $40-\mathrm{min}$ exposure to $51 \mathrm{mM} \mathrm{K}$. In the present study, only a few minutes of high $\mathrm{K}^{+}$were required to obtain effective release of $\left[{ }^{3} \mathrm{H}\right] \mathrm{DA}$. This release was effectively blocked by a $\mathrm{Ca}^{2+}$-free medium. Majocha et al.'s (1981) use of whole brain aggregates may have accounted for some of the differences, since we prepare aggregates from dissected regions of the embryonic brain which contain specific catecholamine systems in our aggregate cultures. Honegger and Richelson (1979) were able to obtain small increases in $\left[{ }^{3} \mathrm{H}\right] \mathrm{DA}$ release in midbrain-hindbrain coaggregates using competitive displacement (chase) experiments. No attempts were made to directly examine release under depolarizing conditions in the latter study, however. Uptake and release of $\left[{ }^{3} \mathrm{H}\right]$ DA have also been observed in dissociated mesencephalic DA neurons in monolayer cultures (Prochiantz et al., 1979; Daguet et al., 1980), as well as in explants of dog nigrostriatal system (Whetsell et al., 1981).

The present study has demonstrated that DA neurons in RMT-CS coaggregate cultures are likely to be spontaneously active and respond to agents that are known to stimulate DA release in the adult nigrostriatal system. These present results, taken with our previous demonstrations that neurons in these coaggregates synthesize, accumulate, and store DA (Kotake et al., 1982), indicate that dopamine neurons maintained in coaggregate cultures display many of the characteristics of adult nigrostriatal DA neurons. Thus, RMT-CS coaggregate cultures represent a viable in vitro model of the mature DA nigrostriatal system. Because the DA neurons appear to develop normally with respect to all morphological, biochemical, and pharmacological features examined, use of the dissociated cell-aggregate system should enable one to examine certain issues concerning their development which cannot be studied in the intact developing brain. In particular, one can examine the physiological and pharmacological behavior of DA neurons during development in the presence or absence of target cells. By this means, the influence of target cells on DA neuron development can be assessed. On the other hand, the potential influence of dopamine neurons on their targets can also be examined by comparing data obtained from RMT-CS coaggregates with aggregates obtained from target cells alone.

\section{References}

Arbilla, S., and S. Z. Langer (1980) Influence of monoamine oxidase inhibition on the release of ${ }^{3} \mathrm{H}$-dopamine elicited by potassium and by amphetamine from the rat substantia nigra and corpus striatum. Naunyn-Schmiedeberg's Arch. Pharmacol. 311: $45-52$.
Catterall, W. A. (1980) Neurotoxins that act on voltage-sensitive sodium channels in excitable membranes. Annu. Rev. Pharmacol. Toxicol. 20: 15-43.

Caviness, J. N., and R. M. Wightman (1982) Use of rapid superfusion to differentiate the release of dopamine from striatal tissue induced by sympathomimetic amines from release induced by potassium. J. Pharmacol. Exp. Ther. 223: 90-96.

Cheramy, A., V. Leviel, and J. Glowinski (1981) Dendritic release of dopamine in the substantia nigra. Nature 289:537542.

Daguet, M. -C., U. DiPorzio, A. Prochiantz, A. Kato, and J. Glowinski (1980) Release of dopamine from dissociated mesencephalic dopaminergic neurons in primary cultures in absence or presence of striatal target cells. Brain Res. 191: 564568.

Golden, G. (1973) Prenatal development of the biogenic amine systems of the mouse brain. Dev. Biol. 33: 300-311.

Hagiwara, S., and L. Byerly (1981) Calcium channel. Annu. Rev. Neurosci. 4: 69-125.

Hemmendinger, L. M., B. B. Garber, P. C. Hoffmann, and A. Heller (1981a) Selective association of embryonic murine mesencephalic dopamine neurons in vitro. Brain Res. 222: 417-422.

Hemmendinger, L. M., B. B. Garber, P. C. Hoffmann, and A. Heller (1981b) Target neuron-specific process formation by embryonic mesencephalic dopamine neurons in vitro. Proc. Natl. Acad. Sci. U. S. A. 78: 1264-1268.

Honegger, P., and E. Richelson (1979) Neurotransmitter synthesis, storage and release by aggregating cell cultures of rat brain. Brain Res. 162: 89-101.

Kotake, C., P. C. Hoffmann, and A. Heller (1982) The biochemical and morphological development of differentiating dopamine neurons coaggregated with their target cells of the corpus striatum in vitro. J. Neurosci. 2: 1307-1315.

Lee, C.-M., B. E. B. Sandberg, M. R. Hanley, and L. L. Iversen (1981) Purification and characterization of a membranebound substance P-degrading enzyme from human brain. Eur. J. Biochem. 114: 315-327.

Lowry, O. H., N. J. Rosebrough, A. L. Farr, and R. J. Randall (1951) Protein measurement with the Folin phenol reagent. J. Biol. Chem. 193: 265-275.

Majocha, R., R. Pearse, R. J. Baldessarini, G. R. DeLong, and $K$. Walton (1981) The noradrenergic system in cultured aggregates of fetal rat brain cells: Morphology of the aggregates and pharmacological indices of noradrenergic neurons. Brain Res. 230: 235-252.

Mulder, A., W. Van der Berg, and J. C. Stoof (1975) Calciumdependent release of radiolabeled catecholamines and serotonin from rat brain synaptosomes in a superfusion system. Brain Res. 99: 419-424.

Nicoll, R. A., C. Schenker, and S. E. Leeman (1980) Substance $\mathrm{P}$ as a transmitter candidate. Annu. Rev. Neurosci. 3: 227268.

Orrego, F. (1979) Criteria for the identification of central neurotransmitters, and their application to studies with some nerve tissue preparations in vitro. Neuroscience 4: 10371057.

Paton, D. M. (1979) Release induced by alterations in extracellular potassium and sodium and by veratridine and scorpion venom. In The Release of Catecholamines from Adrenergic Neurons, D. M. Paton, ed., pp. 323-332, Pergamon Press, New York.

Prochiantz, A., U. DiPorzio, A. Kato, B. Berger, and J. Glowinski (1979) In vitro maturation of mesencephalic dopaminergic neurons from mouse embryos is enhanced in presence of striatal target cells. Proc. Natl. Acad. Sci. U. S. A. 76: $5387-5391$. 
Reubi, J., P. Emson, T. Jessell, and L. Iversen (1978) Effects of GABA, dopamine, and substance $\mathrm{P}$ on the release of newly synthesized ${ }^{3} \mathrm{H}-5$-hydroxytryptamine from rat substantia nigra in vitro. Naunyn-Schmiedeberg's Arch. Pharmacol. 304: $271-275$.

Schwarz, R. D., N. J. Uretsky, and J. R. Bianchine (1980) The relationship between the stimulation of dopamine synthesis and release produced by amphetamine and high potassium levels in striatal slices. J. Neurochem. 35: 1120-1127.
Thompson, J. M., J. R. Whitaker, and J. A. Joseph (1981) ${ }^{3} \mathrm{H}$ dopamine accumulation and release from striatal slices in young, mature and senescent rats. Brain Res. 224: 436-440.

Trendelenburg, U. (1979) Release induced by phenethylamines. In The Release of Catecholamines from Adrenergic Neurons, D. M. Paton, ed., pp. 333 354, Pergamon Press, New York. Whetsell, W. O., Jr., C. Mytilineou, J. Shen, and M. D. Yahr (1981) The development of the dog nigrostriatal system in organotypic culture. J. Neural Transmission 52: 149-161. 